\title{
Jenis-jenis ikan hasil tangkapan nelayan di Kecamatan Tungkal Ilir Kabupaten Tanjung Jabung Barat, Provinsi Jambi
}

[Fish species of fishermens' catches in Kuala Tungkal - Tungkal Ilir Sub-District, Tanjung Jabung Barat Regency, Jambi Province]

\author{
Khaerudin, Afreni Hamidah ${ }^{\bowtie}$, Winda Dwi Kartika \\ Program Studi Pendidikan Biologi, FKIP Universitas Jambi \\ Jl. Raya Jambi -Ma.Bulian KM 15 Mendalo Indah Jambi 36361
}

Diterima: 27 September 2017; Disetujui: 10 April 2018

\begin{abstract}
Abstrak
Penelitian ini bertujuan untuk mengidentifikasi jenis-jenis ikan yang tertangkap oleh nelayan dan dilelang di Tempat Pelelangan Ikan (TPI) serta membandingkannya dengan hasil tangkapan nelayan yang ada di pasar ikan Kuala Tungkal. Sampel ikan diambil dari hasil tangkapan nelayan yang akan dilelang di TPI dan pasar ikan Kuala Tungka dari Juli sampai Agustus 2014. Proses identifikasi dilakukan dengan membandingkan karakteristik morfologi spesimen dengan menggunakan buku identifikasi ikan. Teridentifikasi sebanyak 49 jenis ikan dari 32 famili dan 12 ordo selama penelitian. Ada perbedaan jumlah jenis ikan yang dikoleksi antara TPI dengan pasar ikan. Sebanyak 32 spesies ikan teridentifikasi di TPI dan 13 spesies diantaranya tidak ditemukan di pasar ikan. Dari 36 spesies ikan yang ditemukan di pasar ikan, 17 ikan tidak ditemukan di TPI. Sebanyak 19 jenis ikan ditemukan di kedua lokasi. Perlu dilakukan penelitian serupa pada musim yang berbeda untuk mendapatkan informasi yang utuh mengenai jenis-jenis ikan yang tertangkap di perairan sekitar Tanjung Jabung Barat, Jambi.
\end{abstract}

Kata penting : jenis ikan, nelayan, pasar ikan, tempat pelelangan ikan

\begin{abstract}
The aim of this study was identify fish species caught by fishermen in the fish auction site (FAS) and compare with fish species in the fish market of Kuala Tungkal, Tanjung Jabung Barat Regency, Jambi. Fish samples were collected from FAS and fish market of Kuala Tungkal from July to August 2014. Fish identification was done according to morphometric characteristics of fish speciemens using fish identification books. A total of 49 fish species belonging to 32 families and 11 orders were identified along the study period. The number of fish species found in TPI and fish markets was different. Thirty-two fish species were recognized in FSA and 13 species of which were not found in the fish market. Of the 36 fish species found in the fish market, 17 fish were not collected in the FSA. A total of 19 fish species fish were found in both locations. It is necessary to conduct a similar research in different seasons to obtain a comprehensive information about fish species caught in the waters around Tanjung Jabung Barat, Jambi.uct research in a longer period of time. Thus it is hoped that more fish species may be found only in certainseasons.
\end{abstract}

Keywords: fish species, fisherman, fish market, fish auction site

\section{Pendahuluan}

Kabupaten Tanjung Jabung Barat, Provinsi Jambi secara geografis terletak pada $103^{\circ} 23$ 104²1 Bujur Timur dan 053-0141 Lintang Selatan. Kabupaten Tanjung Jabung Barat, yang beribukota di Kuala Tungkal, memiliki potensi sumber daya perikanan yang besar (Dinas Perikanan Provisi Jambi 2013). Oleh karena itu sumber daya tersebut harus dikelola dengan baik agar kelestariannya dapat terjaga dengan tetap me-

$\triangle$ Penulis korespondensi

Alamat surel: afreni3103@gmail.com manfaatkan secara optimal. Salah satu upaya yang dilakukan guna mengembangkan wilayah Tanjung Jabung Barat adalah dengan menggali potensi sumber daya alam yang ada, terutama potensi sumber daya ikan. Potensi ini belum tergali dan diharapkan pada masa yang akan datang memberikan manfaat ekonomi, manfaat sosial, dan manfaat ekologis bagi pengembangan Kabupaten Tanjung Jabung Barat.

Menurut Ridho (2003), jenis sumber daya perikanan yang terdapat di perairan pesisir Kabupaten Tanjung Jabung Barat terdiri atas beberapa 
kelompok ikan yaitu kelompok ikan pelagis (lemuru, tongkol, tenggiri, terbang), kelompok ikan demersal (kakap, manyung, pari, kurisi, kerapu), dan kelompok ikan lainnya; serta kelompok pelagis non ikan (cumi-cumi, ubur-ubur) dan kelompok udang-udangan (udang ketak, rajungan). Dengan total produksi di Kabupaten Tanjung Jabung Barat sebesar 22.787 ton tahun 2013, sebagian besar produksi perikanan laut tersebut berada di Kecamatan Tungkal Ilir yaitu sebesar 15.055,2 ton (BPS Tanjung Jabung Barat 2015).

Dalam rangka mengoptimalkan produksi perikanan laut, salah satu upaya yang dapat dilakukan adalah hanya menangkap jenis-jenis ikan ekonomis tinggi dan dalam ukuran tertentu saja. Untuk itu, sarana berupa kapal dan alat tangkap menjadi kebutuhan yang amat penting, selain keterampilan sumber daya manusia. Di sisi lain berbagai prasarana telah dibangun dan disediakan oleh Dinas Kelautan dan Perikanan Provinsi Jambi berupa saluran irigasi, benih ikan pantai, dan pos pengawasan. Prasarana lain yang telah disediakan adalah tempat pelelangan ikan, yaitu tempat untuk melelang hasil tangkapan dan produksi nelayan di Kuala Tungkal, Kabupaten Tanjung Jabung Barat (Dinas Perikanan Provinsi Jambi 2013).

Tempat Pelelangan Ikan (TPI) Kuala Tungkal merupakan tempat pelelangan ikan yang bukan hanya menampung jenis ikan laut, tetapi juga semua jenis ikan tangkapan nelayan termasuk jenis ikan payau. Berdasarkan hasil diskusi dengan nelayan dan petugas TPI setempat, mereka mengatakan bahwa hasil tangkapan nelayan semakin berkurang jumlah jenis dan hasil tangkapan karena banyak aktivitas di perairan tersebut, seperti pembangunan pelabuhan transit Kuala Tungkal sebagai pintu gerbang yang menghubungkan Kota Jambi dengan Batam, Malaysia dan Singapura. Hal ini diduga dapat memenga- ruhi keberadaan jenis ikan dan habitat ikan yang ada di perairan laut, khususnya di Kuala Tungkal KabupatenTanjung Jabung Barat, Jambi.

Keberadaan berbagai jenis ikan di suatu perairan menunjukkan kualitas serta kondisi ekologis perairan tersebut (Luzenczyk 2017, Castillo-Rivera et al. 2017). Informasi ilmiah terkini khu-susnya mengenai jenis ikan di TPI dan di Pasar Parit 3 Kuala Tungkal Tanjung Jabung Barat belum pernah dilaporkan. Penelitian mengenai jenis ikan dari daerah lainnya sudah banyak dilakukan, antara lain Genisa (1999), Ernawati (2007), dan Hidayah et al. (2017).

Penelitian ini dilakukan dengan tujuan untuk mengindentifikasi dan mendeskripsikan jenis-jenis ikan hasil tangkapan nelayan, serta membandingkan jenis ikan yang didapatkan antara TPI dengan pasar ikan di Pasir Parit 3 Kuala Tungkal Tanjung Jabung Barat Jambi. Hasil penelitian ini dapat digunakan selain sebagai informasi ilmiah tentang jenis-jenis ikan hasil tangkapan nelayan dan sejauh mana potensi sumber daya perikanan di Tanjung Jabung Barat, juga sebagai tambahan informasi pengayaan materi kuliah keanekaragaman hayati khususnya di Program Studi Pendidikan Biologi Universitas Jambi.

\section{Bahan dan metode}

Penelitian ini merupakan jenis penelitian deskriptif eksploratif, yaitu dengan melakukan pengamatan langsung ke lapangan untuk mengamati aspek-aspek yang tercakup dalam lingkup penelitian untuk menggambarkan secara tepat kondisi empiris pada waktu sekarang. Riset deskriptif dapat bersifat eksploratif yang bertujuan agar peneliti dapat menggambarkan keadaan pada suatu kurun waktu tertentu sebagai dasar untuk membuat keputusan-keputusan. 
Penelitian dilakukan di TPI dan pasar ikan yang ada di Kecamatan Tungkal Ilir, Tanjung Jabung Barat, pada bulan Juli sampai Agustus 2015. Kegiatan penelitian ini diawali dengan observasi lapangan dan pengurusan surat izin penelitian, dilanjutkan dengan pengambilan sampel ikan di lapangan, identifikasi jenis ikan, dan analisis data.

Alat yang digunakan dalam penelitian ini adalah kamera digital dan stoples atau tempat ikan. Bahan yang digunakan adalah alkohol 70\% untuk mengawetkan ikan dan aquades untuk membersihkan sampel sebelum diawetkan.

Pengambilan sampel dilakukan pada pukul 05.00 dan pukul 14.00 yaitu pada saat nelayan melelang hasil tangkapan di tempat pelelangan ikan dan pasar ikan Parit 3 Kuala Tungkal. Setiap jenis ikan yang berbeda secara morfologis diambil untuk diamati dan diidentifikasi. Setelah pengambilan sampel, jenis ikan-ikan yang berbeda secara morfologis dibersihkan dan dimasukkan ke dalam stoples berukuran sedang yang diisi alkohol $70 \%$.

Langkah identifikasi ikan dilakukan dengan mencocokkan spesimen yang telah teridentifikasi seperti gambar atau foto dengan karakter morfologis yang terdapat dalam buku Saanin (1986), White et al.(2006), dan White et al. (2013) sehingga diperoleh informasi tentang jenis ikan hasil tangkapan nelayan.

Data yang diperlukan untuk dianalisis adalah data jenis ikan untuk dibandingkan antara yang ada di pasar ikan dan di TPI. Data penelitian dan informasi yang dikumpulkan untuk diana- lisis, dilakukan melalui pendekatan dokumentasi, observasi dan wawancara. Dokumentasi dilakukan untuk mendapatkan data-data yang ada di TPI melalui Dinas Perikanan, TPI dan pasar ikan. Observasi, merupakan suatu metode pengamatan dan pencatatan data-data yang telah diperoleh secara sistematis. Wawancara dilakukan melalui tanya jawab dengan pihak-pihak terkait, seperti Kepala TPI, Dinas Perikanan, kelompok nelayan, dan lain-lain.

\section{Hasil}

Dari hasil penelitian ditemukan 49 jenis dari 11 ordo dan 32 famili ikan hasil tangkapan nelayan. Dari 11 ordo yang didapatkan selama penelitian, jenis ikan yang paling banyak ditemukan berasal dari ordo Perciformes yang tersebar dalam 16 famili (Tabel 1).

Jenis ikan yang ditemukan di TPI dan pasar ikan tidak seluruhnya sama. Beberapa jenis ikan ditemukan pada kedua tempat, tetapi sebagian jenis-jenis ikan tertentu hanya ditemukan di TPI atau di pasar ikan. Di TPI didapatkan 32 jenis ikan secara keseluruhan, 13 jenis ikan diantaranya tidak ditemukan di pasar ikan, sedangkan di Pasar Ikan Parit 3 ditemukan 36 jenis ikan yang 17 jenis diantaranya tidak ditemukan di TPI. Jenis ikan yang ditemukan pada kedua lokasi penelitian tersebut berjumlah 19 jenis (Tabel 2). Persentase berdasarkan jumlah jenis yang ditemukan antara di TPI dan Pasar Parit 3 Kuala Tungkal disajikan pada Gambar 1, sedangkan beberapa hasil dokumentasi ikan dapat dilihat pada Gambar 2. 


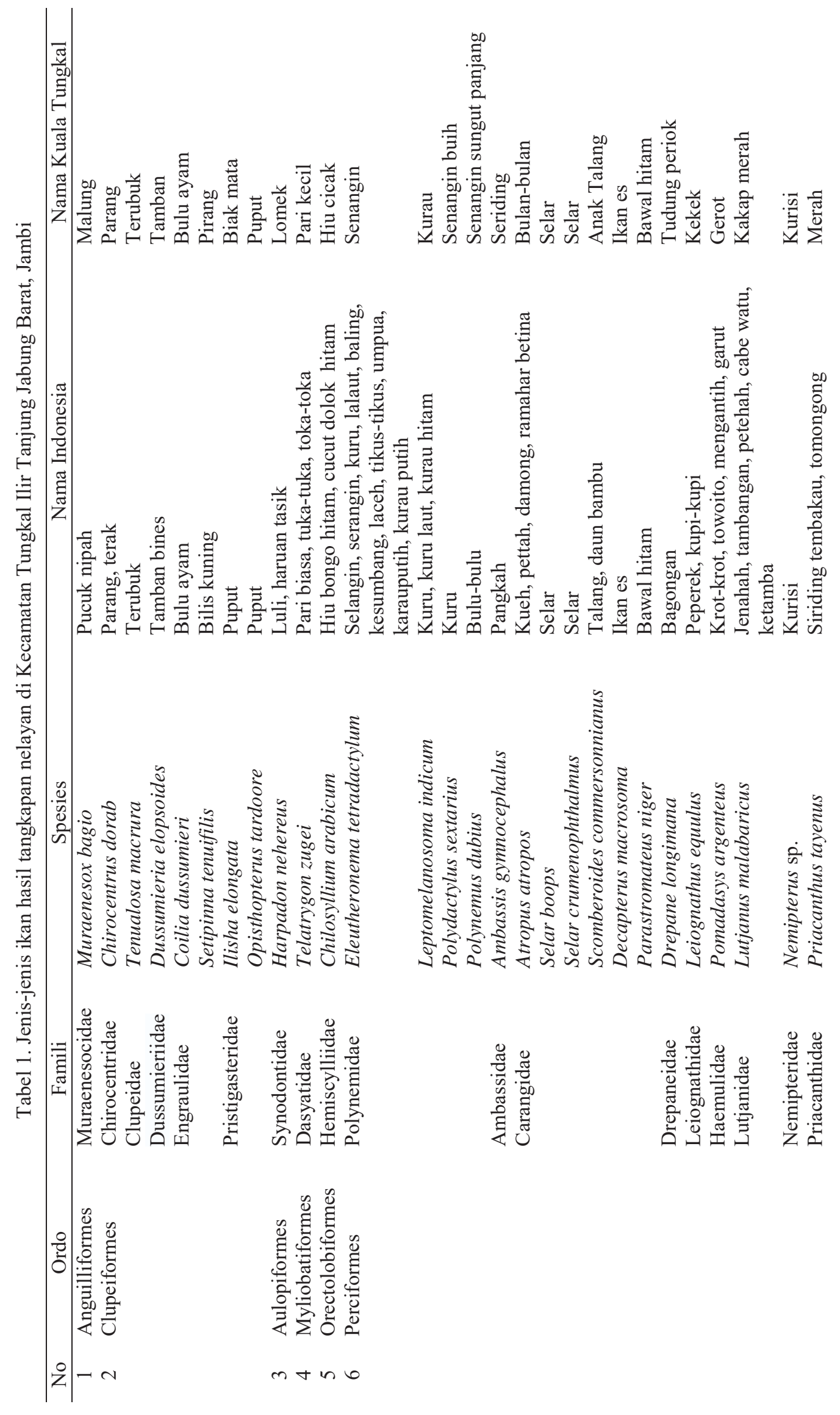




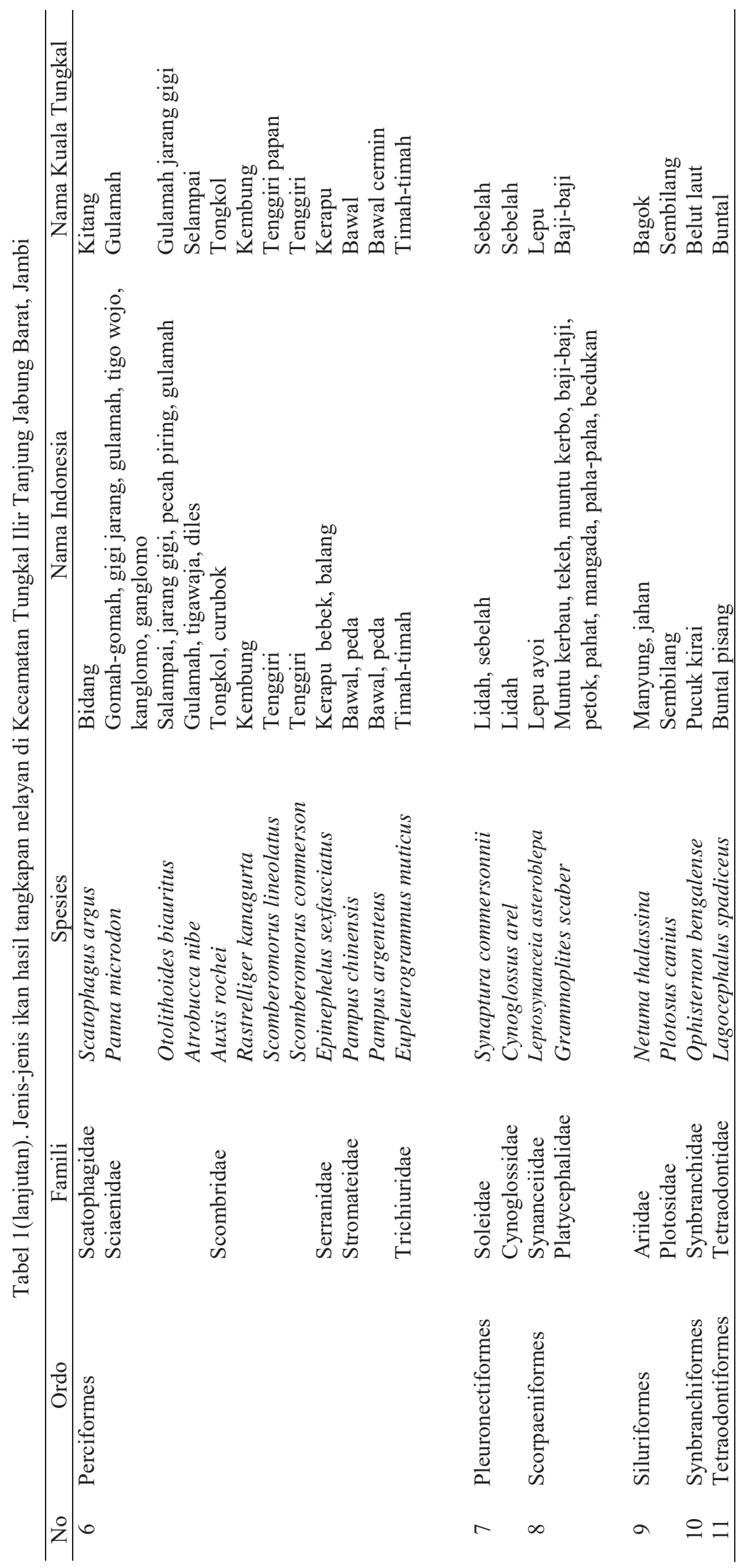


Tabel 2 Jenis ikan yang ditemukan di Tempat Pelelangan Ikan dan Pasar Ikan Parit 3 Kuala Tungkal

\begin{tabular}{|c|c|c|c|c|}
\hline No & $\begin{array}{c}\text { Nama Daerah Kuala } \\
\text { Tungkal }\end{array}$ & Nama Ilmiah & TPI & $\begin{array}{c}\text { Pasar Ikan } \\
\text { Parit } 3\end{array}$ \\
\hline 1 & Seriding & Ambassis gymnocephalus & + & - \\
\hline 2 & Selar & Selar boops & + & + \\
\hline 3 & Selar & Selar crumenophthalmus & + & + \\
\hline 4 & Anak talang & Scomberoides commersonnianus & + & + \\
\hline 5 & Bulan-bulan & Atropus atropos & - & + \\
\hline 6 & Bawal hitam & Parastromateus niger & - & + \\
\hline 7 & Bilis & Stolephorus commersonnii & + & + \\
\hline 8 & Parang & Chirocentrus dorab & + & + \\
\hline 9 & Terubuk & Tenualosa macrura & + & - \\
\hline 10 & Tamban & Dussumieria elopsoides & - & + \\
\hline 11 & Bulu ayam & Coilia dussumieri & + & + \\
\hline 12 & Parikecil & Telatrygon zugei & - & + \\
\hline 13 & Tudung periok & Drepane longimana & - & + \\
\hline 14 & Pirang & Setipinna tenuifilis & + & + \\
\hline 15 & Hiu cicak & Chilosyllium arabicum & + & + \\
\hline 16 & Maco & Leiognathus equulus & + & - \\
\hline 17 & Gerot & Pomadasys argenteus & - & + \\
\hline 18 & Kakap merah & Lutjanus malabaricus & - & + \\
\hline 19 & Malung & Muraenesox bagio & - & + \\
\hline 20 & Baji-baji & Grammoplites scaber & + & - \\
\hline 21 & Sembilang & Plotosus canius & - & + \\
\hline 22 & Senangin & Eleutheronema tetradactylum & + & + \\
\hline 23 & Kurau & Leptomelanosoma indicum & - & + \\
\hline 24 & Senangin buih & Polydactylus sextarius & - & + \\
\hline 25 & Senangin sungut panjang & Polynemus dubius & - & + \\
\hline 26 & Merah & Priacanthus tayenus & + & + \\
\hline 27 & Kitang & Scatophagus argus & + & - \\
\hline 28 & Gulamah jarang gigi & Otolithoides biauritus & + & + \\
\hline 29 & Kembung & Rastrelliger kanagurta & + & + \\
\hline 30 & Tenggiri papan & Scomberomorus lineolatus & + & + \\
\hline 31 & Lomek & Harpadon nehereus & - & + \\
\hline 32 & Gulamah & Panna microdon & + & + \\
\hline 33 & Selampai & Atrobucca nibe & - & + \\
\hline 34 & Kerapu & Epinephelus sexfasciatus & - & + \\
\hline 35 & Sebelah & Synaptura commersonnii & + & - \\
\hline 36 & Sebelah & Cynoglossus arel & + & + \\
\hline 37 & Bawal BB & Pampus chinensis & - & + \\
\hline 38 & Bawal cermin & Pampus argenteus & + & + \\
\hline 39 & Lepu & Leptosynanceia asteroblepa & + & - \\
\hline 40 & Belut laut & Ophisternon bengalense & + & - \\
\hline 41 & Buntal & Lagocephalus spadiceus & + & - \\
\hline 42 & Timah & Eupleurogrammus muticus & + & + \\
\hline 43 & Biak mata & Ilisha elongata & + & + \\
\hline 44 & Puput & Opisthopterus tardoore & + & + \\
\hline 45 & Tongkol & Auxis rochei & + & - \\
\hline 46 & Kurisi & Nemipterus sp. & + & - \\
\hline 47 & Bagok & Netuma thalassina & - & + \\
\hline 48 & Tenggiri & Scomberomorus sp. & + & - \\
\hline \multirow[t]{2}{*}{49} & Ikan es & Decapterus macrosoma & + & - \\
\hline & Jumlah Jenis & & 32 & 36 \\
\hline
\end{tabular}

Keterangan $\quad:(+)=$ ditemukan $(-)=$ tidak ditemukan 


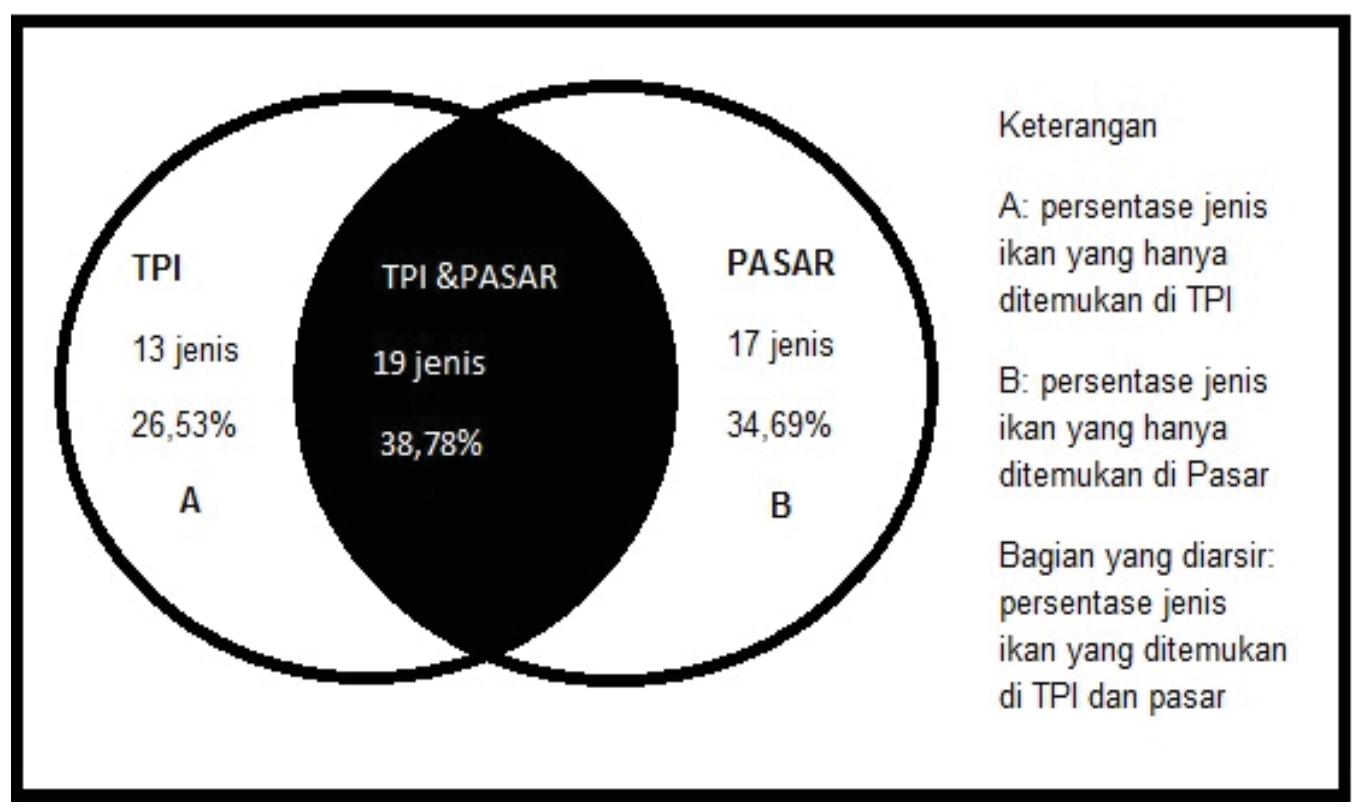

Gambar 1. Persentase jumlah jenis ikan berdasarkan lokasi

\section{Pembahasan}

Hasil identifikasi menunjukkan terdapat 49 jenis ikan dari 11 ordo dan 32 famili hasil tangkapan nelayan, baik di TPI ataupun di Pasar ikan Kuala Tungkal Kabupaten Tanjung Jabung Barat. Dari 11 ordo yang didapatkan selama penelitian, jenis ikan yang paling banyak ditemukan berasal dari Ordo Perciformes yang tersebar dalam 16 famili. Menurut Konishi (2007) Ordo Perciformes merupakan kelompok ikan komersial dan yang paling banyak tersebar di kawasan Asia Tenggara serta terdapat 48 famili yang termasuk dalam Ordo Perciformes. Pada penelitian ini ditemukan 16 famili yang berarti 33\% dari keseluruhan famili dalam ordo Perciformes di kawasan Asia Tenggara dapat ditemukan di Kuala Tungkal. Jumlah sebanyak 49 jenis ini tidak jauh berbeda jika dibandingkan dengan hasil penelitian Prianto \& Suryati (2009) yang mendapatkan 49 jenis ikan di muara Sungai Musi Palembang, sedangkan Hartati et al. (2010) mendapatkan 20 jenis ikan dengan jumlah tangkapan yang relatif rendah.

Alat tangkap yang digunakan nelayan $\mathrm{Pa}-$ sar Parit 3 Kuala Tungkal adalah pukat harimau sehingga jenis ikan yang tertangkap lebih banyak, sedangkan alat tangkap yang digunakan oleh nelayan TPI adalah jaring sehingga ikan yang tertangkap hanya ikan dengan ukuran tertentu. Menurut Chaihua et al. (2008) dan Jarwanto et al. (2014), ukuran dan jenis alat tangkap memengaruhi efisiensi operasi penangkapan, karena semakin lebar ukuran alat tangkap pukat harimau, maka areal dasar perairan yang disapu akan semakin luas. Dengan demikian jumlah biota laut yang tertangkap oleh alat tangkap tersebut juga akan semakin besar.

Musim juga sangat berpengaruh terhadap hasil tangkapan. Dalam satu tahun ada dua musim yaitu musim angin timur timur dan musim angin barat. Pengambilan sampel ikan dilakukan pada bulan Juli sampai Agustus yang merupakan musim angin timur. Hal ini menyebabkan jenis ikan hasil tangkapan nelayan melimpah. Hasil penelitian Hendiarti (2008) menunjukkan bahwa musim angin timur (Juni-September) merupakan musim panen bagi nelayan yang melaut di perairan Samudera Hindia, Laut Jawa dan Selat Sunda. 


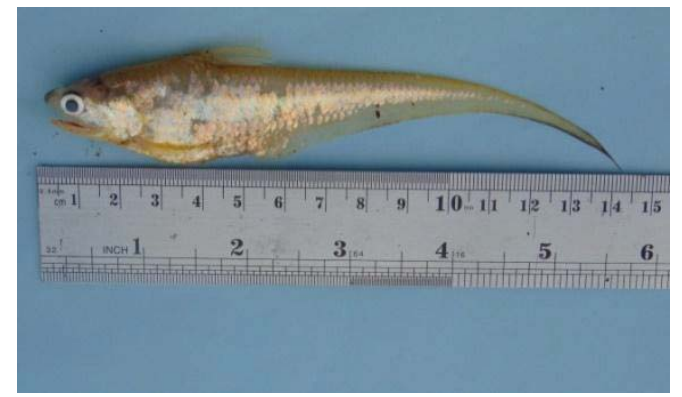

Bulu ayam (Coilia dussumieri)

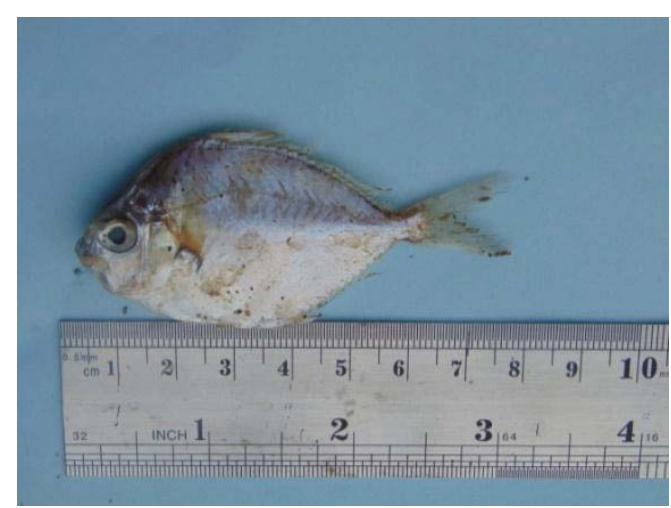

Kekek (Leiognathus equulus)

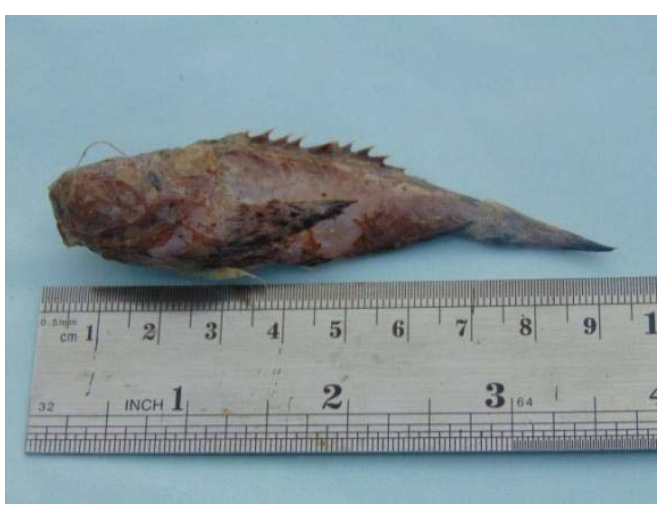

Lepu (Leptosynanceia asteroblepa)

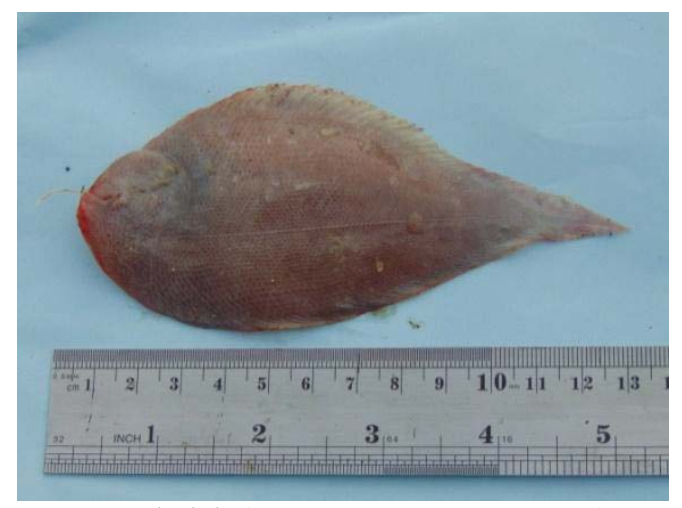

Sebelah (Synaptura commersonnii)

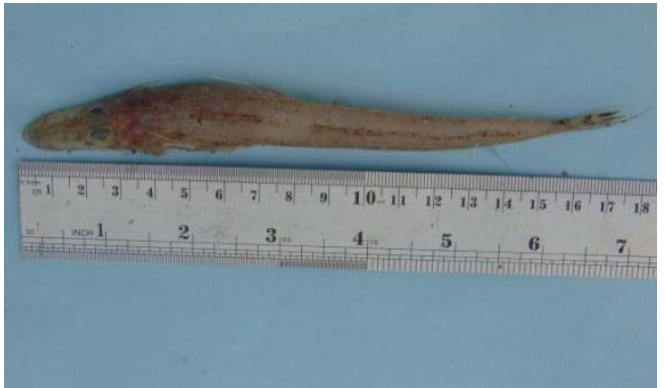

Baji-baji (Grammoplites scaber )

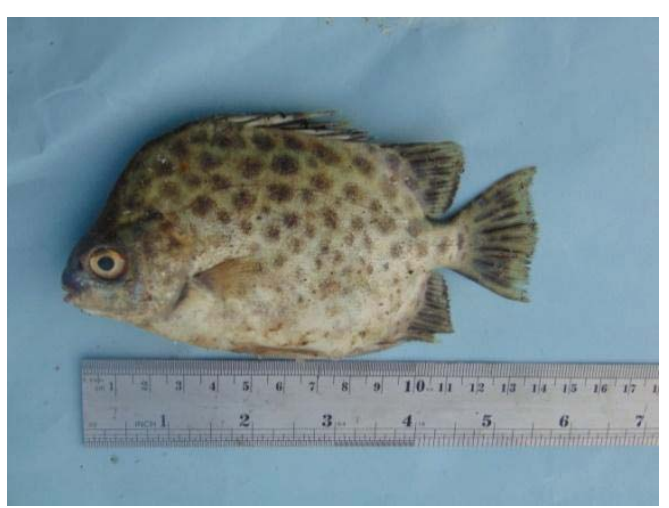

Kitang (Scatophagus argus)

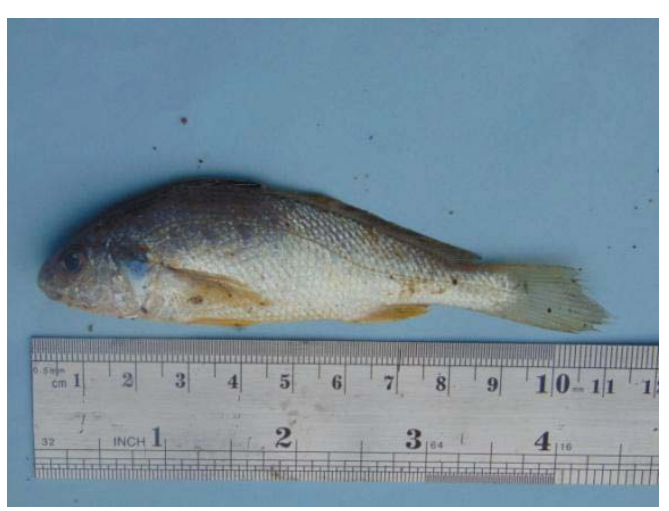

Gulamah (Panna microdon)

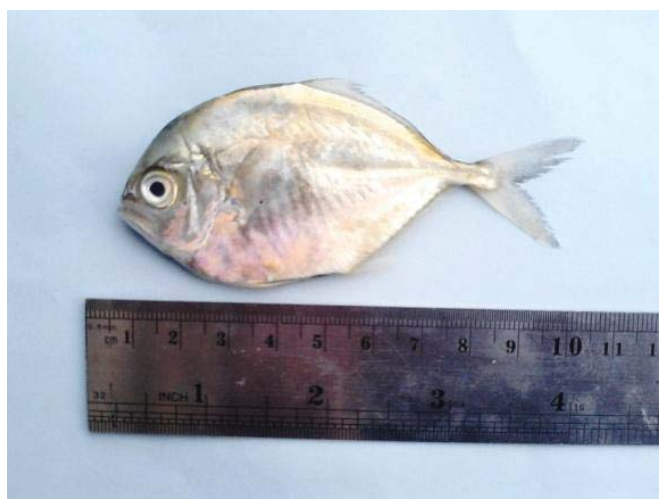

Bulan-bulan (Atropus atropos) 


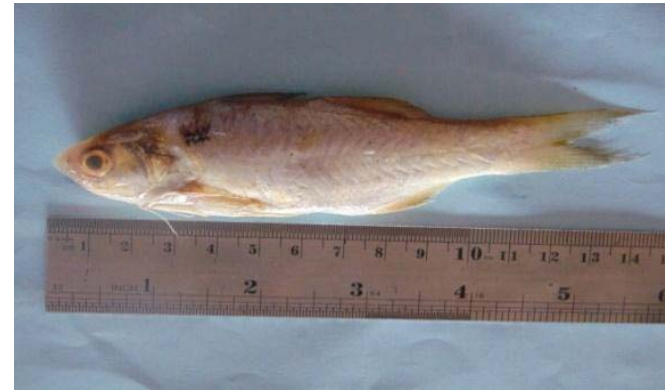

Senangin buih (Polydactylus sextarius)

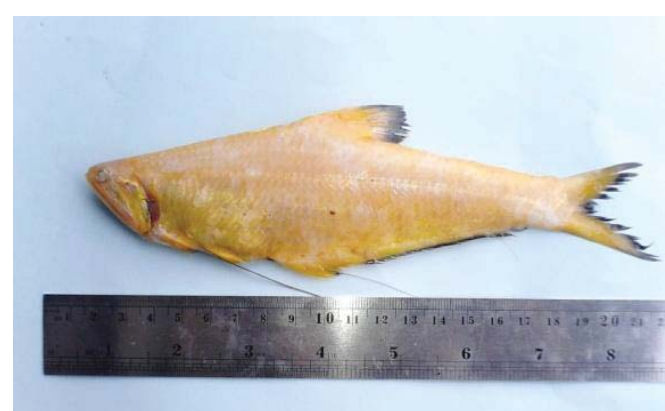

Pirang (Setipinna peonix)

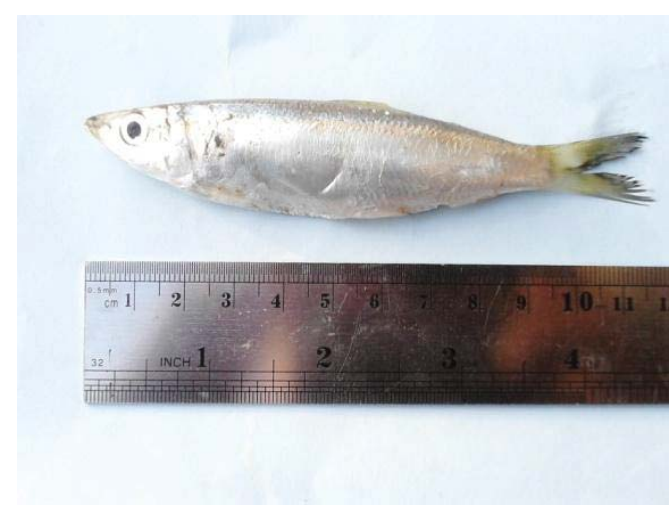

Tamban (Dussumieria elopsoides)

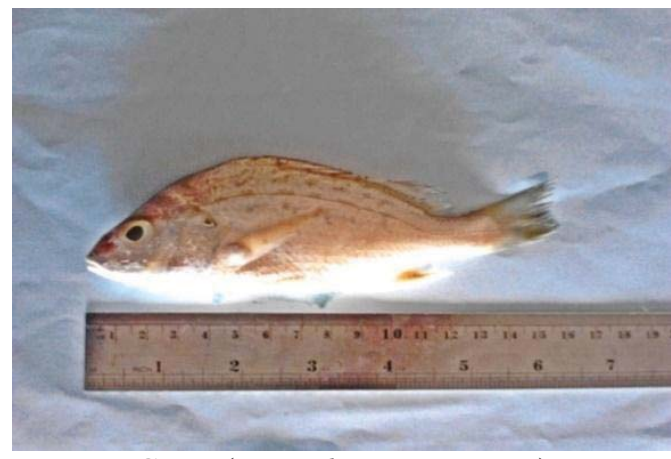

Gerot (Pomadasys argenteus)

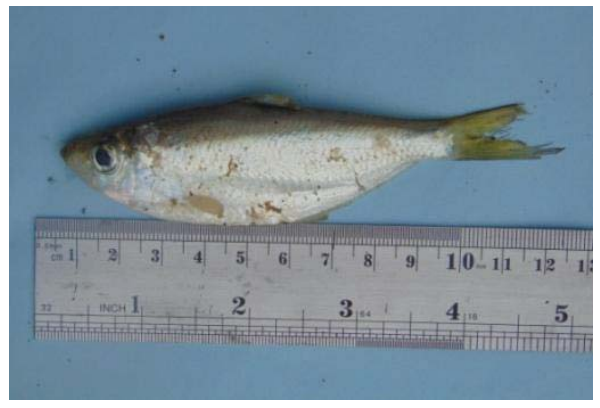

Biak mata (Ilisha elongata)

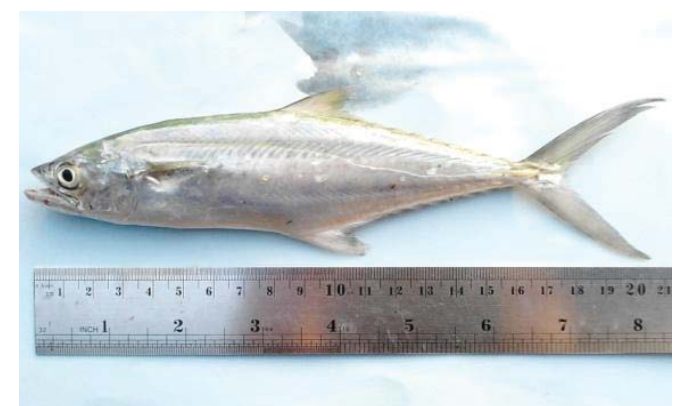

Tenggiri papan (Scomberomorus lineolatus)

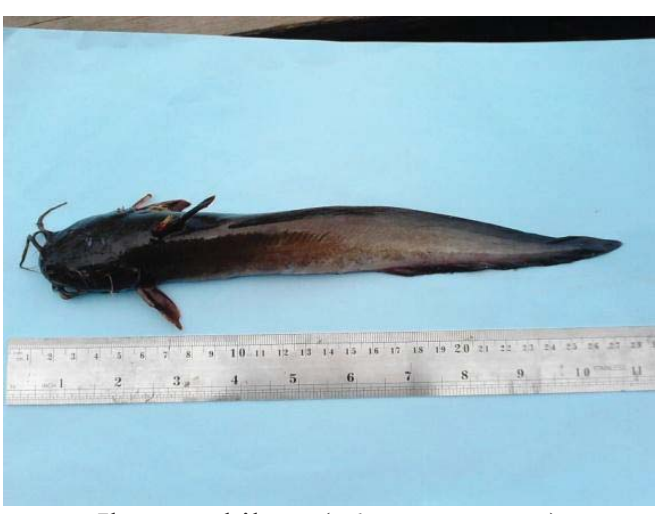

Ikan sembilang (Plotosus canius)

Gambar 2. Beberapa jenis ikan tangkapan nelayan di Kecamatan Tungkal Ilir Tanjung Jabung Barat, Jambi 
Hasil tangkapan nelayan di TPI lebih sedikit daripada nelayan yang berada di Pasar Ikan Parit 3. Hal ini disebabkan daerah jelajah yang berbeda. Pada musim ini kondisi gelombang juga sedang tinggi sehingga memungkinkan terjadinya penyebaran ikan yang tidak merata di sekitar kawasan laut Kuala Tungkal. Penyebaran yang tidak merata ini menyebabkan adanya jenis-jenis ikan tertentu yang banyak didapatkan di Pasar, namun tidak ditemukan di TPI.

Perbedaan jenis ikan hasil tangkapan nelayan TPI dan pasar ikan Parit 3 Kuala Tungkal juga disebabkan oleh perbedaan daerah tangkap nelayan. Daerah tangkap nelayan Pasar Ikan tidak jauh dari pesisir pantai yaitu di kawasan laut dangkal, sedangkan daerah tangkap nelayan TPI jauh dari pesisir pantai yaitu meliputi kawasan laut dalam. Kehidupan ikan di laut tersebar luas baik di kawasan laut dangkal maupun di kawasan laut dalam (Embarek et al. 2017). Hampir seluruh jenis ikan yang didapatkan nelayan baik di TPI ataupun di Pasar Parit 3 Kuala Tungkal bernilai ekonomis penting, antara lain bawal hitam, tongkol, kurisi, tenggiri, kakap merah, senangin, selar, dan ikan kembung. Ikan sampah yang ada di TPI merupakan ikan-ikan yang tidak memiliki nilai ekonomis dan ikan yang berukuran sangat kecil. Penggolongan ikan sampah juga termasuk ikan kiriman dari pasar yaitu ikan yang kondisinya kurang baik dan ikan yang sudah tidak terjual lagi. Ikan sampah yang ada di TPI selanjutnya akan diolah menjadi pelet (pakan ikan) dan ikan asin. Pengolahan ikan sampah ini menghasilkan produk yang memiliki nilai ekonomis sehingga dapat dipasarkan kepada masyarakat.

Berdasarkan hasil wawancara dengan nelayan Kuala Tungkal, daerah tangkapan nelayan adalah perairan Tungkal-Jambi dan Pulau BatamRiau serta Perairan Palembang. Beberapa jenis alat tangkap yang biasa digunakan nelayan di Kabupaten Tanjung Jabung Barat antara lain pukat udang, pukat pantai, jaring insang hanyut, jaring insang tetap, sero, jermal, alat pengumpul kerang, alat pengumpul kepiting, dan jala.

TPI merupakan tempat pembongkaran hasil tangkapan nelayan sekaligus sebagai tempat pelelangan hasil tangkapan tersebut. Nelayan yang ada di TPI terikat kerjasama dengan Departemen Kelautan dan Perikanan (DKP) Provinsi Jambi. Bentuk kerjasama tersebut dalam pendanaan yang diperlukan dalam kegiatan nelayan, termasuk peralatan dan kapal yang digunakan. Hasil tangkapan yang dilelang di tempat ini yaitu udang dan ikan.

Nelayan yang ada di TPI biasanya pergi melaut selama satu minggu hingga satu bulan. Jumlah awak kapal biasanya 4 sampai 7 orang. Selain itu ada pula nelayan yang pulang dalam satu hari saja, yaitu hanya untuk mengantarkan ikan-ikan sampah ke TPI. Nelayan harian ini adalah nelayan yang menggunakan kapal berukuran kecil, sehingga kapasitas muatan kapal juga sedikit. Hal ini tidak memungkinkan untuk nelayan pergi melaut dalam jangka waktu satu minggu atau satu bulan.

Hasil penelitian yang telah dilakukan di TPI dan Pasar Ikan Parit 3 Kuala Tungkal, menunjukkan bahwa Kuala Tungkal memiliki sumber daya ikan yang cukup tinggi. Dari keseluruhan jenis ikan hasil tangkapan nelayan ada beberapa jenis ikan yang selalu banyak tertangkap oleh nelayan yaitu ikan baliak mata, selar, dan gulama. Ikan-ikan tersebut selalu banyak tertangkap karena ikan baliak mata, selar, dan gulama hidup secara bergerombolan dan hidup di perairan pantai sehingga ketiga jenis ikan tersebut mudah didapatkan. Selain itu ada pula jenis ikan yang hanya didapat pada musim tertentu seperti ikan 
merah (Priacanthus tayenus). Ikan merah hanya didapat pada saat bulan purnama atau ketika air laut sedang tinggi, karena ikan ini hidup di kawasan perairan dalam.

\section{Simpulan}

Selama penelitian diperoleh 49 jenis ikan dari 11 ordo dan 32 famili hasil tangkapan nelayan, baik di Tempat Pelelangan Ikan maupun di Pasar ikan Kuala Tungkal Kabupaten Tanjung Jabung Barat. Alat tangkap dan daerah jelajah menjadi faktor penting banyaknya keanekaragaman jenis-jenis ikan hasil tangkapan nelayan.

\section{Daftar Pustaka}

BPS Tanjung Jabung Barat. 2015. Tanjung Jabung Barat dalam Angka. https://randal jambi.files.wordpress.com/2016/05/tanjun g-jabung-barat-dalam-angka-2015.pdf.

Castillo-Rivera M, Ortiz-Burgos S, Zárate-Hernández R. 2017. Temporal changes in species richness and fish composition in submerged vegetation habitat in Veracruz, Mexico. Acta Ichthyologica et Piscatoria, 47(1): 23-32.

Chaihua MA, You K, Zhang M, Li F, and Chen D. 2008. A preliminary study on the diversity of fish species and marine fish faunas of the South China Sea. Journal of Ocean University of China (Oceanic and Coastal Sea Research), 7(2): 210-214

Dinas Perikanan Provinsi Jambi. 2013. Statistik Perikanan Laut. Jambi.

Embarek R, Amara R, Kara MH. 2017. Fish assemblage structure in shallow waters of The Mellah Lagoon (Algeria): Sesonal and spatial distribution pattern and relation to environmental parameters. Acta Ichthyologica et Piscatoria, 47 (2): 133-144

Ernawati T. 2007. Distribusi dan komposisi jenis ikan demersal yang tertangkap trawl pada musim barat di Perairan Utara Jawa Tengah. Jurnal Ikhtiologi Indonesia, 7(1): 41-45

Genisa AS. 1999. Pengenalan jenis-jenis ikan laut ekonomi penting di Indonesia. Oseana, 24(1): 17-38
Hartati ST, Wahyuni IS, Indarsyah IJ. 2010. Pemanfaatan sumber daya ikan di perairan Gugusan Pulau Pari, Kepulauan Seribu. Jurnal Penelitian Perikanan Indonesia, 16(1): 9-19.

Hendiarti N. 2008. Hubungan antara keberadaan ikan pelagis dengan fenomena oseanografi dan perubahan iklim musiman berdasarkan analisis data penginderaan jauh. Majalah Ilmiah Globe 10(1):19-25.

Hidayah N, Boesono H, Setiyanto I. 2017. Analisis tingkat efisiensi Tempat Pelelangan Ikan (TPI) di Kabupaten Batang. Journal of Fisheries Resources Utilization Management and Technology, 6(3):74-80.

Konishi Y. 2007. Guide to Identification to Order and Family and Main Characters of Larvae of Commercially Important Fish in the South East Asia Region. Thailand. The Regional Training Workshop on Larval Fish identification and Fish Early Life History Science. SEAFDEC/TD. Samut Prakan, Thailand 16-31 May 2007.

Jarwanto S, Isnaniah, Syofyan I. 2014. Efficiency of trawl cod end for catching result in Lambur Luar East Muara Sabak East Tanjung Jabung Jambi Province. Jurnal online Mahasiswa (JOM) Bidang Perikanan dan Ilmu Kelautan Universitas Riau, 1(2): $1-13$

Luzenczyk A.2017. Change in biological reference points under different biological, fishery, and environmental factors. Acta Ichthyologica Et Piscatoria, 47(1): 41-51.

Prianto E, Suryati NK. 2009. Komposisi jenis dan potensi sumber daya ikan di Muara Sungai Musi. Jurnal Penelitian Perikanan Indonesia. 16(1):1-8.

Ridho MR. 2008. Potensi sumber daya ikan dari arah pengembangan wilayah pesisir Tanjung Jabung Barat Provinsi Jambi. Jurnal Pengelolaan Lingkungon \& SDA, 7(3): I48-157.

Saanin H. 1986. Taksonomi dan Kunci Identifikasi Ikan. Vol. 1 dan II. Bina Cipta. Jakarta.

White WT, Last PR, Stevens JD, Yearsley GK, Fahmi, Dharmadi. 2006. Economically Important Sharks and Rays of Indonesia. Australian Centre for International Agricultural Research (ACIAR). Australia. 
White WT, Last PR, Dharmadi, Faizah R, Chodrijah U, Prisantoso BI, Pogonoski JJ, Puckridge M, Blaber SJM. 2013. Market
Fishes of Indonesia. Australian Centre for International Research (ACIAR). Australia. 